\title{
Stakeholder perceptions of ecosystem services of the Wami River and Estuary
}

\author{
Catherine G. McNally ${ }^{1,2}$, Arthur J. Gold ${ }^{1}$, Richard B. Pollnac $^{3}$ and Halima R. Kiwango ${ }^{4}$
}

\begin{abstract}
Management of riverine and coastal ecosystems warrants enhanced understanding of how different stakeholders perceive and depend upon different kinds of ecosystem services. Employing a mixed methods approach, this study compares and contrasts the use and perceptions of upstream residents, downstream residents, tourism officials, and conservation organizations regarding the value of 30 ecosystem services provided by the Wami River and its estuary in Tanzania, and investigates their perceptions of the main threats to this system. Our findings reveal that all of the stakeholder groups place a high value on the provision of domestic water, habitat for wild plants and animals, tourism, and erosion control, and a relatively low value on the prevention of saltwater intrusion, refuge from predators, spiritual fulfillment, nonrecreational hunting, and the provision of traditional medications and inorganic materials for construction. Differences emerge, however, between the groups in the value assigned to the conservation of riverine and estuarine fauna and the provision of raw materials for building and handicrafts. Declining fish populations and an increasing human population are identified by the residents and conservation employees, respectively, as their prime concerns regarding the future conditions of the Wami River and its estuary. These groups also acknowledge increasing salinity levels and the loss of mangroves as other key concerns. The identification of these mutual interests and shared concerns can help build common ground among stakeholders while the recognition of potential tensions can assist managers in balancing and reconciling the multiple needs and values of these different groups.
\end{abstract}

Key Words: ecosystem services; stakeholders; values; Tanzania

\section{INTRODUCTION}

The dialogue pertaining to the management of riverine and coastal ecosystems has evolved over the past decade to increasingly consider ecosystem services because of their ability to link ecosystem structure and function to human well-being (Saunders et al. 2015). However, as highlighted in a recent review article (Liquete et al. 2013), 95\% of the studies conducted to date have focused on the biophysical and/or economic aspects of ecosystem services. Although this information is critical to informing management decisions, experience has shown that conflicts and disenchantment can arise when stakeholder values and the potential trade-offs arising from differing values within and among stakeholder groups are not properly considered (Adams et al. 2003, McShane et al. 2011, Vira et al. 2012).

Ecosystem services are "a wide range of conditions and processes through which natural ecosystems, and the species that are part of them, help sustain and fulfill human life" (Daily et al. 1997:2). The Millennium Ecosystem Assessment classifies ecosystem services into four groups: regulating services, e.g., water purification/waste treatment, flood and drought mitigation; supporting services, e.g., habitat for terrestrial, riverine, and estuarine flora and fauna, nursery function, nutrient cycling; provisioning services, e.g., food, fiber, timber for construction and fuel; and cultural services, e.g., recreation, tourism, education, aesthetics, and spiritual significance.

In this study, different groups of stakeholders were asked to order perceived levels of importance by distributing a fixed number of counters to rank numerous ecosystem services in relation to one another (e.g., Brown et al. 2008, Agbenyega et al. 2009, Adekola et al. 2012, Hicks et al. 2013). This approach was selected because it requires the stakeholder to prioritize among a number of different ecosystem services. In this type of ranking exercise the stakeholders are forced to distribute a finite number of counters among many services, providing insightful information on tradeoffs. The need for explicit and systematic assessments of tradeoffs has been identified by numerous researchers as imperative for more informed management decisions (Granek et al. 2010, McShane et al. 2011, Vira et al. 2012, Needles et al. 2015). Many studies have focused specifically on local residents' value of ecosystem goods and services, but only a few have examined multiple stakeholder groups simultaneously to ascertain potential synergies and trade-offs (e.g., Agbenyega et al. 2009, MartínLópez et al. 2012, Hicks et al. 2013). Having multiple stakeholder groups rank the same set of ecosystem services provides a method for identifying mutual interests, as well as potential conflicts, which is critical in helping managers balance and reconcile multiple needs and values.

Tanzania's Saadani National Park, in particular, serves as an interesting setting for examining how different groups of stakeholders directly and indirectly use and value the ecosystem services provided by a protected riverine and coastal area. Saadani National Park contains approximately $30 \mathrm{~km}^{2}$ of coastal forest, which, along with the Wami River, Estuary, and mangrove forests within the park, were classified as exceptional resource values ${ }^{[1]}$. The coastal forests of Tanzania were identified as one of the world's biodiversity hotspots, i.e., "areas featuring exceptional concentrations of endemic species and experiencing exceptional loss of habitat" (Myers et al. 2000:853). This designation resulted in international NGOs placing a very high priority on their

\footnotetext{
${ }^{1}$ Department of Natural Resources Science, University of Rhode Island, Kingston, Rhode Island, ${ }^{2}$ Coastal Resources Center, University of Rhode Island, Narragansett, Rhode Island, ${ }^{3}$ Department of Marine Affairs, University of Rhode Island, Kingston, Rhode Island, ${ }^{4}$ Tanzania National Parks.
} 
conservation (Republic of Tanzania/UNDP/GEF [date unknown]) augmenting earlier efforts by the Tanzanian government and western donors focused on conserving mangrove ecosystems that had been identified as undergoing rapid decline (Mangora 2011). Its location on the coast offers tourists the unique opportunity to enjoy traditional wildlife safaris, as well as a boat safari, and time at the beach within one destination. Many communities surrounding the park have been established in the area for centuries, i.e., Saadani village is one of the oldest Swahili communities in East Africa, and rely heavily upon natural resources for their subsistence and livelihoods.

The need for enhanced understanding of how different stakeholders perceive and depend upon ecosystem services has been identified as a critical research priority (Pereira et al. 2005, Carpenter et al. 2009, Barbier et al. 2011, Braat and de Groot 2012). The benefits of incorporating stakeholders' needs and values can lead to more balanced and equitable management decisions with greater levels of legitimacy and compliance (Menzel and Teng 2010). This is particularly relevant for the rural poor in developing countries who often disproportionately rely upon the natural environment for their sustenance and livelihoods. Despite this dependence, the majority of biodiversity conservation efforts undertaken in Tanzania within the past 50 years have adopted a top-down approach with limited attention to local residents' needs and priorities (Mangora 2011, Sigalla 2013). Information is warranted on the perspectives and needs of poorer local residents because their dependence on ecosystem services, and provisioning ecosystem services in particular, from the natural environment may foster priorities that differ from those of international conservation organizations and tourism operators catering to wealthy international tourists (Roe and Walpole 2010). We describe a study conducted in the Wami River/ Estuary complex of East Africa that is dominated by a protected national park and surrounded by villages with high levels of poverty.

We compare and contrast the use and perceptions of four different stakeholder groups, i.e., upstream residents living adjacent to the Wami River, downstream residents living adjacent to the Wami River Estuary and coast, tourism officials, and conservation organizations, regarding the value of ecosystem services provided by the Wami River and its estuary, and determine what they perceive as the main threats to this system. We seek to address key information gaps identified by Sarmett and Anderson (2008), specifically by identifying the value of ecosystem services to basin residents and more detailed socioeconomic information pertaining to human uses of water. This information can be useful for informing future management efforts within the Wami River Estuary. Specifically, we ask the following research questions:

1. Are there differences in the perceived importance of each ecosystem service category within and between the stakeholder groups?

2. Which regulating, supporting, cultural, and provisioning ecosystem services, provided by the Wami River and its estuary, are most and least important among our targeted stakeholder groups?

3. What are the main concerns of these stakeholders regarding the future conditions of the Wami River and its estuary?
4. How do the upstream and downstream residents utilize the Wami River and Estuary in their daily lives and which provisioning ecosystem services are deemed most important for their subsistence and livelihoods?

\section{Site description}

Saadani National Park (SANAPA), Tanzania's only national park to bridge terrestrial and marine environments, is located approximately $80 \mathrm{~km}$ north of Dar es Salaam and $27 \mathrm{~km}$ west of Zanzibar within the Districts of Pangani and Bagamoyo (latitude $5^{\circ} 20^{\prime} 6^{\circ} 17 ' \mathrm{~S}$; longitude $38^{\circ} 45^{\prime} 39^{\circ} 02^{\prime} \mathrm{E}$; Fig. 1 ). SANAPA protects a range of different habitats including acacia woodlands, open grasslands, coastal forests, riparian vegetation, mangroves, and coral reefs, and encompasses the final 20 kilometers of the Wami River and its estuary. The Wami River and Estuary are keystones of the Saadani National Park ecosystem because their riparian and estuarine areas support riverine forests and mangrove stands that are extremely diverse both in floral and faunal species (Baldus et al. 2007, McNally 2007, SANAPA 2009). The abundant and diverse bird population associated with the mangrove forests at the mouth of the Wami River Estuary is a major tourist attraction, and the Wami River and adjacent riparian vegetation provide important habitat for crocodiles (Crocodylus niloticus), hippopotami (Hippopotamus amphibious), and black and white colobus monkeys (Colobus angolensis). Moreover, because it is the only perennial river within SANAPA's boundaries, it serves as a critical source of drinking water for the terrestrial animals and residents during the dry season (Tobey 2008). Although the levels of ecotourism are still low in comparison to many of Tanzania's other national parks (SANAPA 2009), it is expected to continue to increase with improvements in transportation and park infrastructure.

Fig. 1. Study sites.

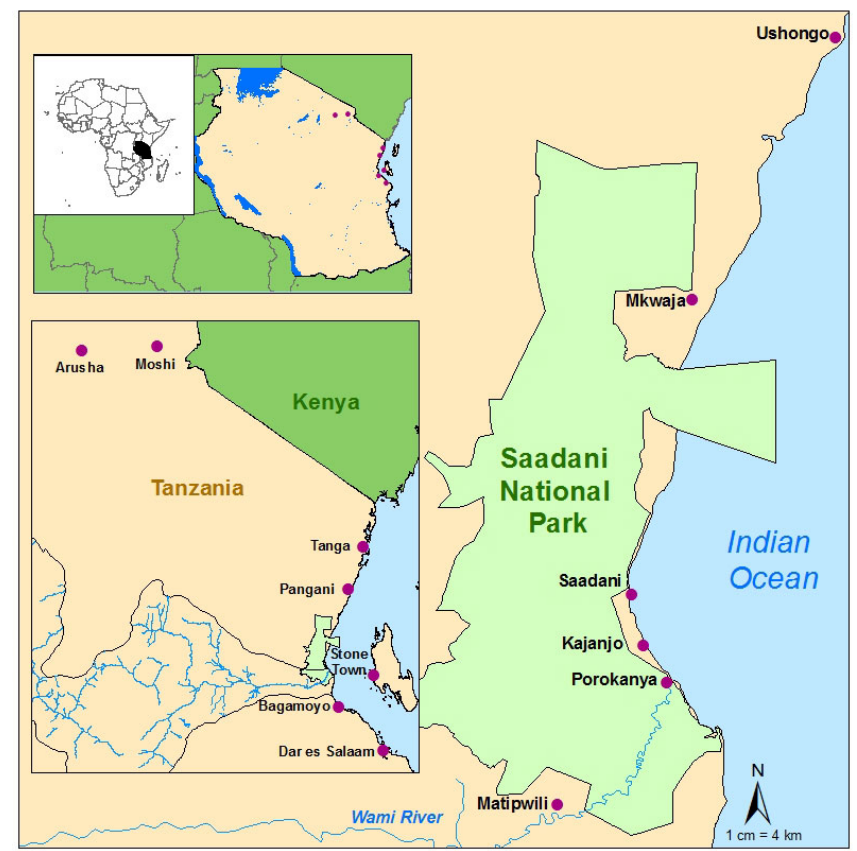


SANAPA is surrounded by rural villages with persisting high poverty rates (Research and Analysis Working Group 2005). Forty percent of the village inhabitants live below the poverty line, $89 \%$ do not have access to a piped or protected water source, and $94 \%$ do not have electricity. Additionally, there is high population growth, high infant mortality rates (i.e., 105 deaths per 1000 births), low investment, and most households lack access to markets, credit, and insurance (Research and Analysis Working Group 2005).

For the local stakeholders within this study, we focused on an upstream and downstream village that are in close proximity to the Wami River and its estuary. The upstream village of Matipwili (population 2149) is located approximately $20 \mathrm{~km}$ upstream of the Wami River Estuary, and is bordered on the north and south by SANAPA and the Wami River, respectively. The primary livelihoods for the residents are small scale agriculture and fishing (Torell et al. 2012). The downstream village of Saadani village (population 1433) primarily has settlements located approximately $9 \mathrm{~km}$ north of the Wami River Estuary, and is bordered on the north, south, and west by SANAPA and the Indian Ocean on the east (Torell et al. 2012). Fishing is the main livelihood activity in Saadani. The other two stakeholder groups include the domestic and international hotel owners and tourism operators who bring tourists to SANAPA, and international conservation employees who either work within/around SANAPA or are familiar with the Wami River and Estuary ecosystems. The hotel owners and tourism operators bringing visitors to SANAPA are located in the neighboring villages and other tourist destinations, such as Zanzibar, Dar es Salaam, and surrounding Mt. Kilimanjaro. The conservation employees are those who work within/around SANAPA or are familiar with the area and represent organizations and agencies that include the World Wide Fund for Nature, the Wildlife Conservation Society, IUCN, the Tanga Coastal Zone Center, the Institute for Marine Sciences, etc.

\section{METHODS}

Our study employed a mixed methods approach comprising participatory rapid appraisal (PRA) exercises with small groups of local community members and face-to-face surveys to gather extensive qualitative and quantitative data on the stakeholders' use and perceived value of ecosystem services, as well as their main concerns regarding future conditions of the Wami River and its estuary. The PRA questions focused specifically on the types of provisioning ecosystem services utilized by the local communities. The survey instrument included separate sections on ecosystem services and stakeholder concerns. The appropriateness and clarity of the PRA and survey questions were evaluated in pilot testing with a community in Tanzania before commencing data collection. To ensure data quality control, the study followed accepted protocols (Pollnac and Crawford 2000), and prior to commencing data collection the lead author conducted two days of thorough training with the Tanzanian enumerators. In cases where it was deemed that the respondents may need additional clarification to answer the question, a list of standard definitions, word for word translations, and short explanations were created to assist the enumerators in relaying the identical information to all survey respondents. The lead author stayed in the field with the survey team throughout the data collection and held daily debriefing meetings with the field team to further ensure quality control of the survey data.
The PRA participants were selected with the assistance of key informants from each village to ensure that we were reaching a wide array of users. A stratified sampling strategy design was used to collect data on a random sample of upstream and downstream community members while a snowball technique was used to identify the tourism operators and conservation organization employees (Pollnac and Crawford 2000, Babbie and Benaquisto 2009). The PRA activities and village surveys were conducted in August 2009, while the tourism and NGO respondents were surveyed in August and September 2009. The Tanzanian enumerators conducted the PRA small group discussions and village surveys in Kiswahili while the main author along with one other enumerator from Tanzania conducted the tourism operator and conservation organization surveys in English.

Nineteen focus groups were convened within the upstream and downstream communities as part of the PRA activities. The number of participants ranged from 3-10 individuals per focus group, and separate groups were convened for men and women. A total of 31 upstream (12 males, 19 females) and 47 downstream (33 males, 14 females) community members participated. Concurrent with the PRA activities, 41 upstream community members ( $8 \%$ of the total households), 44 downstream community members ( $10 \%$ of the total households), 30 tourism operators, and 30 conservation organization employees completed the survey. Among the downstream residents, 22 were randomly selected from the 7 subvillages located in the heart of Saadani, 11 each were randomly selected from Saadani's subvillages of Kajanjo and Porokanya.

The PRA activities took 2 to 3.5 hours to complete depending upon the size of the group. On average, the surveys took approximately $1.5-2.5$ hours for the residents to complete and 1 hour for the tourism officials and conservation employees to complete. The former took longer because of the inclusion of the additional questions pertaining to the provisioning ecosystem services and a greater number of open-ended questions. To minimize respondent fatigue, the more participatory aspects of the survey instrument were interspersed throughout and the demographic section was completed last.

The ecosystem services and stakeholder concerns portions of the survey instrument were used for all of the stakeholder groups; the additional provisioning ecosystem services section was only used for the local residents in the upstream and downstream communities. The ecosystem services section adapted the methods developed by Agbenyega et al. (2009). Similar to their study, four tables were created, each corresponding to one of the Millennium Ecosystem Assessment ecosystem services categories, i.e., regulating, supporting, cultural, and provisioning. The specific services listed in each table were compiled from the literature drawing predominantly upon Daily et al. (1997), De Groot et al. (2002), Millennium Ecosystem Assessment (2005), Korsgaard (2006), and Agbenyega et al. (2009; see Table 1 for a list of the specific ecosystem services included within each category). Although these prior studies included nutrient cycling and soil formation as separate types of supporting services, we used habitat as a catch all because the overall quality of the latter is affected by changes in the former (Twilley and Rivera-Monroy 2009). 
Table 1. Ecosystem services the survey respondents were asked to rank.

\begin{tabular}{ll}
\hline \hline Ecosystem & Ecosystem Services \\
Service & \\
\hline Regulating & Water Purification (clean water) \\
& Flood mitigation (water retention capacity) \\
& Minimizing drought \\
& Erosion control/stabilization of land by vegetation \\
& Coastal protection of beach and coastlines from storm \\
& surges, waves, and floods \\
& Prevention of saltwater intrusion \\
& Delivery of water and sediments to maintain nursery \\
& areas \\
& Habitat for wild riverine and estuarine plant animal \\
species (e.g., fish, hippos, migratory birds, etc.) \\
Plant conservation (riparian and mangrove species) \\
Riverine/estuarine species conservation \\
Terrestrial species conservation (drinking water \\
provided by the river during the dry season) \\
Nursery habitats (i.e., places/locations for food and \\
protection for juveniles) \\
Refugium function (i.e., places/locations that provide \\
shelter and protection for animals from their \\
predators) \\
Recreation \\
Tourism \\
Intrinsic value \\
Spiritual and inspirational information (religious \\
significance/spiritual-sacred sites) \\
Aesthetic (appreciation of natural features) \\
Science and education (opportunities for formal and \\
informal education and training) \\
Historic information \\
Water for domestic uses (drinking, cooking, bathing) \\
Fish/shrimp for subsistence and commercial fisheries \\
Fertile land for flood-recession agriculture and grazing \\
Wildlife for hunting (non-recreational) \\
Vegetables and fruit production \\
Fiber/organic raw material for building/handicrafts \\
Fuelwood/charcoal projection \\
Traditional medicinal plants \\
Inorganic raw materials for construction (gravel, sand, \\
clay) \\
Employment \\
& \\
& \\
& \\
& \\
& \\
& \\
&
\end{tabular}

\section{Assessing ecosystem service priorities}

Within each ecosystem service category, each respondent was given 25 marbles (counters) and asked to allocate them among the list of specific ecosystem services provided by the Wami River and Estuary according to their personal perceptions of their relative importance. After completing this activity for each of the ecosystem categories, each respondent was then asked to consider the full suite of ecosystem services listed in each individual table together and allocate the 25 marbles (counters) according to their perceptions of the relative importance of each complete set in relation to the other sets, i.e., permitting comparisons among the four basic ecosystem categories.

Given that there were an unequal number of services within each category, we calculated an expected value (i.e., Expected Value = $25 / \mathrm{N}$, where $\mathrm{N}$ denotes the total number of services within that particular category) to normalize the data and permit relative comparisons between the services of the different categories. The numerical values assigned to each individual service by the different stakeholder groups were analyzed for differences with Kruskal-Wallis and Bonferroni-corrected Mann-Whitney U tests. For comparisons among the ecosystem service categories as a whole, Kruskal-Wallis and Bonferroni-corrected MannWhitney $U$ tests were employed to examine whether statistically significant differences existed between the different stakeholder groups as well as within each individual stakeholder group. For all of the Mann-Whitney U results discussed in the text, we display the significance value ( $\mathrm{p}$ values) as well as the effect size statistic, denoted by $d$, which estimates the magnitude of an effect and serves as a measure of practical significance (Nakagawa and Cuthill 2007). Values of $d<0.3$ signify a small effect, $\geq 0.3$ to $<$ 0.5 signify a medium effect, and $\geq 0.5$ signify a large effect (Cohen 1988).

\section{Evaluating concerns}

In the main concerns section of the survey, each respondent was asked, "What do you see as possible problems for the Wami River and Wami River Estuary?" The primary author classified the responses into different categories using data-driven inductive thematic analysis (Boyatzis 1998). This process was repeated by one of the other coauthors to validate the assignment and themes and ensure reliability. The overall percentages of each stakeholder group identifying the specific categories were calculated. ChiSquare tests for equality of proportions were employed to examine whether the perceived problems differed across the stakeholder groups and Cramer's V were calculated to measure effect size. Values $<0.3$ signify a small effect, $\geq 0.3$ to $<0.5$ signify a medium effect, and $\geq 0.5$ signify a large effect (Gravetter and Wallnau 2004).

\section{Establishing levels of use}

The expanded provisioning ecosystem services section in the survey instrument, which was only given to the local residents, was designed to augment the information gathered in the participatory group discussions, and included questions to gather information on the most common activities conducted at the Wami River and Estuary, the sources of water for drinking, cooking, and bathing, as well as the quantity of water collected per day. Each respondent was asked whether they visit the Wami River and Estuary, and if so, how often and for what purposes. The resulting data were analyzed with descriptive statistics.

The PRA group discussions were convened for the local residents within upstream and downstream communities to gather specific information on the fish and crustacean species captured in the river and adjacent coastal waters for food and livelihoods as well as the specific mangrove and riparian species utilized for medicinal purposes, fuelwood, and building materials. Once the species lists were compiled, the focus group participants were asked to collectively rate each species overall importance on a scale of 1 (not very important) to 4 (very important).

\section{RESULTS}

\section{Stakeholders' perceptions of the relative importance of each} category of ecosystem services

The average relative importance assigned to each of the ecosystem service categories by the stakeholder groups ranged from 17 to 
$37 \%$ (Fig. 2). Looking across groups, the median value assigned to the entire set of provisioning services by the upstream and downstream residents was significantly higher than the median values assigned by the tourism officials $(p=0.008, d=0.32$ and $p$ $=0.003, \mathrm{~d}=0.35$, respectively) and conservation employees $(\mathrm{p}=$ $0.017, \mathrm{~d}=0.29$ and $\mathrm{p}=0.011 \mathrm{~d}=0.30$, respectively). The perceived level of importance for the supporting services was similar among the four stakeholder groups while the upstream residents valued the regulating services significantly lower than the tourism officials $(\mathrm{p}=0.016, \mathrm{~d}=0.29)$ and conservation employees $(\mathrm{p}=0.023, \mathrm{~d}=$ $0.28)$. Similarly, the upstream residents also valued the cultural services significantly lower than the tourism officials $(\mathrm{p}=0.008, \mathrm{~d}$ $=0.32)$ and conservation employees $(\mathrm{p}=0.011, \mathrm{~d}=0.31)$.

Fig. 2. Relative valuation assigned to each category of ecosystem services by residents, tourism, and conservation stakeholders. (Columns represent mean values. Vertical error bars represent the standard error of the mean).

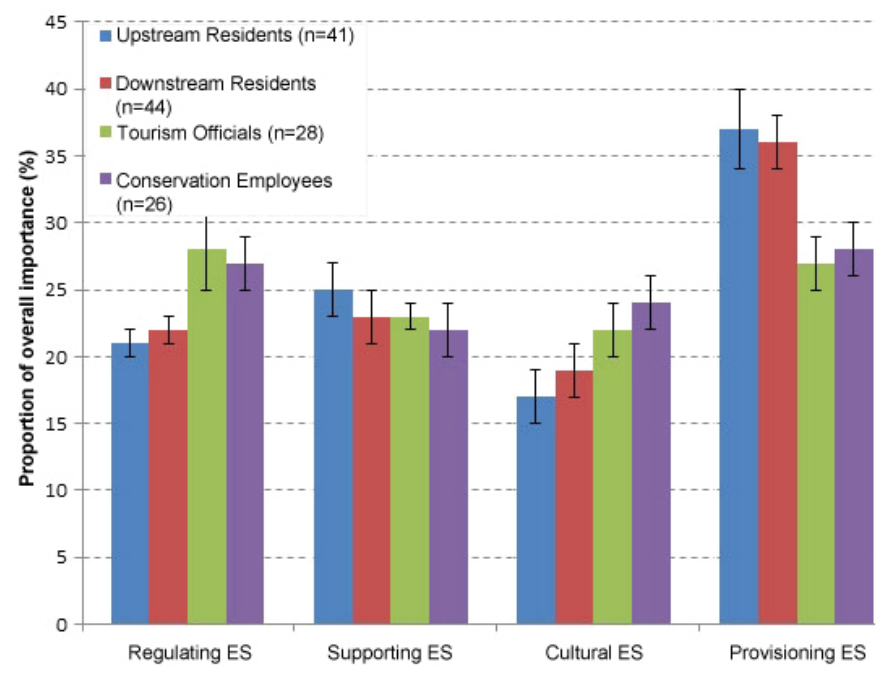

Examining results within each stakeholder group, the upstream and downstream residents placed a significantly higher level of importance on provisioning ecosystem services than the other services ( $p<0.0001$, $d$ ranged from 0.40 to 0.63 ). Both groups of residents placed a significantly lower level of importance on the cultural ecosystem services ( $\mathrm{p}<0.05$, $\mathrm{d}$ ranged from 0.27 to 0.63 ). The tourism officials also perceived the cultural ecosystem services as significantly less valuable than provisioning $(\mathrm{p}=0.006, \mathrm{~d}=0.37)$ and regulating services $(\mathrm{p}=0.012, \mathrm{~d}=0.34)$ while the conservation employees assigned similar levels of importance to all four categories.

\section{Interstakeholder results: perceptions of the relative importance of the individual ecosystem services within each category ${ }^{[2]}$}

\section{Regulating services}

All four of the stakeholder groups surveyed in this study perceived erosion control as a valuable regulatory ecosystem service while the prevention of saltwater intrusion was not valued highly by any group (Table 2). The residents and tourism operators also placed high importance on water purification. The perceived importance of the Wami River and Estuary in maintaining nursery habitats was significantly higher for the residents and conservation employees than the tourism operators $(p<0.0001, d=0.43$ and $\mathrm{p}=0.003, \mathrm{~d}=0.4$, respectively; Table 2 ).

\section{Supporting services}

All stakeholder groups perceived the existence of healthy ecosystems/habitat for wild plants and animals as the most valuable supporting service followed by plant and terrestrial animal conservation (Table 2). None of the stakeholder groups perceived refugium function as a particularly valuable service. The perceived importance of the Wami River and Estuary in riverine/ estuarine animal conservation was significantly higher for the tourism and conservation employees than the residents $(\mathrm{p}<$ $0.0001, \mathrm{~d}=0.39$ and $\mathrm{p}=0.002, \mathrm{~d}=0.29$, respectively).

\section{Cultural services}

All stakeholder groups perceived tourism as a valuable cultural ecosystem service. No group perceived spiritual fulfillment as important (Table 2). The tourism officials placed the highest value on tourism while the conservation employees placed the highest value on the intrinsic value of biodiversity conservation, i.e., conserving an element of biodiversity for its own sake without the intention of using it. Residents placed high value on science and education as well as a significantly higher value on aesthetics than both the tourism officials $(\mathrm{p}<0.001, \mathrm{~d}=0.36)$ and conservation employees $(p=0.015, d=0.23)$. The tourism officials placed a significantly higher value on recreation than the conservation employees $(\mathrm{p}=0.008, \mathrm{~d}=0.41)$ and residents $(\mathrm{p}=$ 0.001, $\mathrm{d}=0.31$; Table 2).

\section{Provisioning services}

All four of the stakeholder groups surveyed perceived domestic water as a very valuable provisioning ecosystem service; median values were twice the expected value (Table 3 ). Within the resident group, upstream residents placed a significantly higher value on flood recession agriculture than the downstream residents $(\mathrm{p}=$ $0.001, \mathrm{~d}=0.38$ ). Downstream residents placed a significantly higher value on fish and shrimp for subsistence and commercial fisheries than the upstream residents $(p=0.015, d=0.26)$. While all stakeholder groups perceived traditional medicinal plants and inorganic raw materials as relatively unimportant, the downstream residents placed a significantly lower value on vegetable and fruit production than the other stakeholder groups ( $\mathrm{p}<0.05$, d ranged from 0.29 to 0.37 ). Furthermore, they also placed a significantly higher value on organic raw materials for building and handicrafts than the tourism officials $(\mathrm{p}=0.014, \mathrm{~d}$ $=0.29)$ and conservation employees $(\mathrm{p}=0.006, \mathrm{~d}=0.32)$.

\section{Interstakeholder results: perceptions of main concerns}

Seventy-three percent of upstream and downstream residents identified declining fish populations as a prime concern regarding the future conditions of the Wami River and its estuary (Table 4). Fifty percent or more of the downstream residents also identified increasing salinity levels, declining shrimp populations, and the loss of mangroves as key concerns. The second most common concern voiced by the upstream residents was increasing human population, which was the most frequent concern identified by the conservation employees. Forty percent of the conservation employees also identified declining fish populations, increasing salinity levels, and the loss of mangroves as primary concerns. 
Table 2. Relative importance of regulating, supporting, and cultural ecosystem services provided by the Wami River and Estuary as perceived by 85 local residents, 28 tourism operators, and 26 conservation employees. The survey respondents distributed 25 marbles among 7 regulation ES (expected value = 3.6), 6 supporting ES (expected value = 4.2), and 7 cultural ES (expected value $=3.6$ ). The values in the table are median (interquartile range). Those in bold and italics denote values 50\% higher and lower, respectively, than the expected value.

\begin{tabular}{|c|c|c|c|c|}
\hline $\begin{array}{l}\text { Ecosystem } \\
\text { Service Category }\end{array}$ & Ecosystem Service & $\begin{array}{c}\text { Residents } \\
(\mathrm{n}=85) \\
\text { Median (IQR) }\end{array}$ & $\begin{array}{c}\text { Tourism Officials } \\
(\mathrm{n}=28) \\
\text { Median (IQR) }\end{array}$ & $\begin{array}{c}\text { Conservation Employees } \\
(\mathrm{n}=26) \\
\text { Median (IQR) }\end{array}$ \\
\hline \multirow[t]{7}{*}{ Regulating } & Water purification & $4(3)$ & $5(3)$ & $3.7(3)$ \\
\hline & Flood mitigation & $3(3)$ & $3(1)$ & $3(2)$ \\
\hline & Drought minimization & $3(4)$ & $3(2.5)$ & $4(4)$ \\
\hline & Erosion control & $4(2)$ & $4(2)$ & $4(2)$ \\
\hline & Coastal Protection & $3(3)$ & $3(3.5)$ & $3.7(3)$ \\
\hline & Prevention of saltwater intrusion & $2(4)$ & $3(2.5)$ & $2(1)$ \\
\hline & Maintenance of nursery habitats & $5^{\mathrm{a}+* * *}(3)$ & $3^{\mathrm{b}}(2)$ & $4^{\mathrm{a}}(2)$ \\
\hline \multirow[t]{6}{*}{ Supporting } & Habitat for wild plants and animals & $8^{\mathrm{a}^{*}}(2)$ & $6^{\mathrm{b}}(1.5)$ & $6^{\mathrm{b}}(4)$ \\
\hline & Nursery habitat & $4^{a^{*}}(2)$ & $3^{\mathrm{b}}(1)$ & $4^{\mathrm{a}, \mathrm{b}}(2)$ \\
\hline & Refuge from predators & $2.1(3)$ & $3(2)$ & $3(3)$ \\
\hline & Plant conservation (riparian/mangrove spp.) & $4(2)$ & $4(0.5)$ & $4(2)$ \\
\hline & Riverine/estuarine animal conservation & $3^{\mathrm{a}^{* * *}}(3)$ & $4^{\mathrm{b}}(2)$ & $4^{\mathrm{b}}(2)$ \\
\hline & $\begin{array}{l}\text { Terrestrial animal conservation (drinking } \\
\text { water) }\end{array}$ & $4(2.5)$ & $4(2)$ & $4(2)$ \\
\hline \multirow[t]{7}{*}{ Cultural } & Intrinsic value & $3^{\mathrm{a}^{*}}(2.5)$ & $4^{\mathrm{b}}(2)$ & $6^{\mathrm{c}}(3)$ \\
\hline & Aesthetics & $4^{a^{*}}(2.5)$ & $2^{\mathrm{b}}(3.5)$ & $3^{c}(2)$ \\
\hline & Spiritual fulfillment & $2(4)$ & $2(2)$ & $2(3)$ \\
\hline & Tourism & $5^{\mathrm{a}^{*}}(3)$ & $6^{\mathrm{b}}(2.5)$ & $5^{\mathrm{a}, \mathrm{b}}(2)$ \\
\hline & Recreation & $2^{\mathrm{a}^{* *}}(4)$ & $4^{\mathrm{b}}(2.5)$ & $3^{\mathrm{a}}(2)$ \\
\hline & Science and education & $5^{\mathrm{a}^{*}}(3)$ & $4^{\mathrm{b}}(2.5)$ & $4^{a, b}(2)$ \\
\hline & Historic information & $3(2.5)$ & $3(2)$ & $3(3)$ \\
\hline
\end{tabular}

Kruskal-Wallis and Bonferroni-corrected Mann-Whitney U tests were conducted.

${ }^{\dagger}$ Statistical differences between group values within rows that have a different letter are significantly different.

$* \mathrm{p}<0.05 ; * \mathrm{p}<0.01$.

Additional water abstractions from the Wami River for upstream agriculture as well as proposed irrigation withdrawals for a biofuel project just upstream of the park boundary were causes of concern for at least one-third of the conservation employees and $29 \%$ of the upstream residents. In comparison to the other stakeholder groups, many of the tourism officials noted during the surveys that it was very difficult to predict foreseeable problems because they only visit the Wami River and Estuary on occasion.

\section{Village-based results on provisioning ecosystem services}

Given the significantly high value assigned to the provisioning ecosystem services by the upstream and downstream residents, we delved into the reasons the local residents visit the Wami River and Estuary. There was substantial variability between subvillages in the extent of water collection for drinking and cooking that did not relate to their upstream or downstream locations, but appear to link to availability of alternative water sources. Several subvillages (Matipwili, an upstream village, and Porokanya, a downstream village) obtain virtually all of their domestic needs from direct collection from the river. These villages have no alternative sources. Where alternative sources exist, 12 out of 33 surveyed households directly use the river for their major water needs. These estimates are conservative because residents often purchase water from peddlers who obtain water from local rivers. Additionally, during the dry season Wami River usage can expand because of the loss of wells and drying of intermittent rivers. Of the residents gathering their own water, the average amount collected per visit for the residents ranged from $46 \mathrm{~L}$ to $106 \mathrm{~L}$.

In addition to the important role that the Wami River serves in providing water for domestic uses, 38 out of 85 upstream and downstream surveyed households reported visiting the Wami River, Estuary, and nearshore coastal waters for artisanal fishing. A total of 63 fish species were identified by the PRA participants as being caught for food with 42 of them $(67 \%)$ rated as very important. The two downstream subvillages located in closest proximity to the estuary had 13 of the 22 surveyed respondents visiting the river, estuary, and nearshore coastal waters for commercial fishing. A total of 29 fish species are harvested for income, and of those $16(55 \%)$ were rated as very important. Interestingly, only two species whitespotted grouper (Epinephelus coeruleopunctatus) and greasy grouper (Epinephelus tauvina) were identified as being very important sources of both food and income. Visits to the Wami Estuary and nearshore coastal waters for shrimping were reported by 18 out of 44 surveyed downstream respondents with Acetes erythraeus, Fenneropenaeus indicus, Penaeus monodon, Penaeus semisulcatus, and Periclimenes holthuisi all rated as very important.

During the PRA exercises, the upstream residents stressed the critical role the Wami River serves in their flood recession agriculture. Corn, rice, peas, and potatoes were identified as the greatest sources of food and cash income. Millet was also identified as an important source of food while tomatoes are often 
Table 3. Relative importance of provisioning ecosystem services provided by the Wami River and Estuary as perceived by 41 upstream residents, 44 downstream residents, 28 tourism operators, and 26 conservation employees. The survey respondents distributed 25 marbles among 10 provisioning ES (expected value $=2.5$ ). The values in the table are median (interquartile range). Those in bold and italics denote values $50 \%$ higher and lower, respectively, than the expected value.

\begin{tabular}{|c|c|c|c|c|}
\hline Provisioning Ecosystem Services & $\begin{array}{c}\text { Upstream } \\
\text { Residents } \\
(\mathrm{n}=41) \\
\text { Median (IQR) }\end{array}$ & $\begin{array}{c}\text { Downstream } \\
\text { Residents } \\
(\mathrm{n}=44) \\
\text { Median (IQR) }\end{array}$ & $\begin{array}{l}\text { Tourism Officials } \\
\qquad(\mathrm{n}=28) \\
\text { Median (IQR) }\end{array}$ & $\begin{array}{c}\text { Conservation } \\
\text { Employees } \\
(\mathrm{n}=26) \\
\text { Median (IQR) }\end{array}$ \\
\hline Domestic water & $5(2)$ & $5(2)$ & $5(2)$ & $5(2)$ \\
\hline Subsistence/commercial fisheries & $3^{\mathrm{a}+*}(2.5)$ & $4^{\mathrm{b}}(3.75)$ & $3^{\mathrm{a}}(2)$ & $3^{\mathrm{a}, \mathrm{b}}(1)$ \\
\hline Flood recession agriculture & $4^{a * * *(2)}$ & $2.5^{\mathrm{b}}(3)$ & $4^{\mathrm{a}}(2)$ & $3^{\mathrm{a}, \mathrm{b}}(1)$ \\
\hline Nonrecreational hunting & $0(2)$ & $2(3)$ & $2(3)$ & $1(2)$ \\
\hline Fruit production & $3^{\mathrm{a}^{*}}(1.5)$ & $1.5^{\mathrm{b}}(3)$ & $3^{\mathrm{a}}(1.5)$ & $3^{\mathrm{a}}(2)$ \\
\hline Traditional medicinal plants & $1(2)$ & $1(2)$ & $1(2)$ & $1(2)$ \\
\hline Fuelwood/charcoal & $2(3)$ & $1.5(3)$ & $1(2)$ & $1(2)$ \\
\hline Organic raw materials for building and handicrafts & $2^{a, b^{*}}(3)$ & $2.45^{\mathrm{a}}(1.75)$ & $1^{\mathrm{b}}(1.5)$ & $1^{\mathrm{b}}(2)$ \\
\hline Inorganic raw materials for construction & $1(2)$ & $1(2)$ & $2(1)$ & $1(2)$ \\
\hline Employment & $2(2)$ & $2(4.75)$ & $3(1)$ & $3(1)$ \\
\hline
\end{tabular}

Kruskal-Wallis and Bonferroni-corrected Mann-Whitney U tests were conducted.

${ }^{\dagger}$ Statistical differences between group values within rows that have a different letter are significantly different.

$* \mathrm{p}<0.05 ; * \mathrm{p}<0.01$.

grown for income. Residents also noted visiting the Wami River and Estuary to gather building materials and medicinal plants. Residents indicated that the most important mangrove species for building materials are Avicennia marina, Bruguiera gymnorrhiza, Ceriops tagal, Rhizophora mucronata, and Xylocarpus granatum, and the most important riparian species are Grewia bicolor, Spirostachys africanas, Olea europaea spp. africana, and Ficus sur. Although the ranking of medicinal plants by upstream and downstream residents overall was quite low in comparison to some of the other provisional ecosystem services, it is important to note that the residents identified the fruit of $R$. mucronata and $X$. granatum as very important for treating a variety of medical ailments.

\section{DISCUSSION}

Synergies and tensions among the stakeholder groups

Stakeholders tend to assign the greatest priorities to services most closely linked to their livelihood. The upstream and downstream residents placed a high priority on the provisioning services tightly linked to their sustenance and main sources of income. Likewise, the tourism officials highly valued tourism while the conservation employees assigned a high priority to intrinsic values. However, the results of our survey also revealed a good deal of consensus among the stakeholder groups in regards to specific ecosystem services deemed important and unimportant, which could be informative when designing future management initiatives. Each of the stakeholder groups placed a high value on the provision of domestic water, habitat for wild plants and animals, tourism, and erosion control, and a relatively low value on the prevention of saltwater intrusion, refuge from predators, spiritual fulfillment, nonrecreational hunting, and the provision of traditional medications and inorganic materials for construction.

In addition, stakeholders displayed a clear appreciation for services that other stakeholders depended on. For example, the supply of domestic water from the Wami River was perceived as the most important provisioning service by all the surveyed groups, even though three-quarters of the downstream residents live in villages with some access to alternative sources of domestic water and the tourism trade and conservation employees do not use the Wami River for domestic water. This is a strong indication that all stakeholder groups are concerned about the welfare of those local residents who rely heavily on the Wami for such critical services. Flood recession agriculture, subsistence and commercial fisheries, vegetable and fruit production, and employment were all perceived as the next most valuable provisioning services by the tourism officials and conservation employees. Although many of Tanzania's past biodiversity conservation efforts have not adequately taken into account the needs and values of local users, this recognition suggests that there may be growing awareness and appreciation. Roe and Walpole (2010) draw attention to the recent trend of many conservation organizations trying to expand their missions to also consider poverty alleviation and genuinely incorporate local communities. The local residents placed a high priority on habitat and tourism, and assigned similar priorities to nursery habitat and the conservation of riparian and mangrove flora and terrestrial fauna as the conservation employees. This combined with the overlap in many aforementioned provisioning services suggests that there is common ground among the groups that future management efforts within the Wami River and Estuary can build upon.

In addition to identifying potential areas of mutual interest, the results of our survey also highlighted possible tensions among the stakeholder groups that managers need to bear in mind and account for in future management efforts. Although both the upstream and downstream residents concurred with conservation and tourism stakeholders on the importance of habitat, they placed a significantly lower value on intrinsic values and conservation of riverine and estuarine fauna. Additionally, the downstream residents placed a significantly higher value on the provision of raw materials for building and handicrafts than the other groups. The results of our focus group discussions highlighted that they rely on a number of mangrove species for 
Table 4. Main concerns of each stakeholder group regarding the future conditions of the Wami River and Estuary.

\begin{tabular}{|c|c|c|c|c|c|}
\hline $\begin{array}{l}\text { Categories of Stakeholders } \\
\text { Main Concerns* }\end{array}$ & $\begin{array}{c}\text { Upstream } \\
\text { Residents } \\
(\mathrm{n}=44) \\
(\%)\end{array}$ & $\begin{array}{c}\text { Downstream } \\
\text { Residents } \\
(\mathrm{n}=41) \\
(\%)\end{array}$ & $\begin{array}{c}\text { Tourism } \\
\text { Officials } \\
(\mathrm{n}=30) \\
(\%)\end{array}$ & $\begin{array}{l}\text { Conservation } \\
\text { Employees } \\
(\mathrm{n}=30) \\
(\%)\end{array}$ & $\begin{array}{c}\mathrm{X}^{2}(3,145) \\
(\text { Cramer's V) }\end{array}$ \\
\hline Decline in Fish & 73.2 & 72.7 & 13.3 & 40 & $34.59, \mathrm{p}<0.0001\left(0.488^{\star}\right)$ \\
\hline Decline in Shrimp & 39 & 59.1 & 3.3 & 36.7 & $23.81, \mathrm{p}<0.0001,\left(0.405^{*}\right)$ \\
\hline Increasing Salinity & 46.3 & 63.6 & 16.7 & 40 & $16.26, p=0.001\left(0.335^{\ddagger}\right)$ \\
\hline Increasing Human Population & 51.2 & 38.6 & 13.3 & 46.7 & $11.66, \mathrm{p}=0.009,\left(0.284^{\dagger}\right)$ \\
\hline Loss of Mangroves & 34.1 & 50 & 13.3 & 40 & $10.72, \mathrm{p}=0.013,\left(0.272^{\dagger}\right)$ \\
\hline $\begin{array}{l}\text { Water Abstractions for } \\
\text { Biofuel Production }\end{array}$ & 29.3 & 13.6 & 10 & 33.3 & $7.95, p=0.047,\left(0.234^{\dagger}\right)$ \\
\hline $\begin{array}{l}\text { Water Abstractions for } \\
\text { Domestic Use }\end{array}$ & 29.3 & 15.9 & 10 & 16.7 & $4.83, p=0.185,(0.182)$ \\
\hline $\begin{array}{l}\text { Water Abstractions for } \\
\text { Upstream Agriculture }\end{array}$ & 29.3 & 15.9 & 13.3 & 36.7 & $6.80, p=0.079,(0.217)$ \\
\hline Other & 39 & 15.9 & 30 & 46.7 & $9.22, \mathrm{p}=0.026,\left(0.252^{\dagger}\right)$ \\
\hline
\end{tabular}

* The primary author classified the responses into different categories using data-driven inductive thematic analysis (Boyatzis 1998 ). This process was repeated by one of the other coauthors to validate the assignment and themes and ensure reliability, ${ }^{\dagger}$ small effect size, ${ }^{\star}$ medium effect size.

these materials, i.e., A. marina, B. gymnorrhiza, C. tagal, $R$. mucronata, and X.granatum. However, if not managed properly, overharvesting could lead to trade-offs with many of the other highly valued ecosystem services associated with mangroves, e.g., erosion control, coastal protection, habitat provision, aesthetics, tourism, etc.

\section{The prioritization of ecosystem services by each stakeholder group}

The high and low level of relative importance assigned by local residents to the categories of provisioning and cultural services as a whole, respectively, aligns with the results of other studies conducted in developing countries (Brown et al. 2008, Iftekhar and Takama 2008, Warren-Rhodes et al. 2011). To our surprise, the tourism officials placed a significantly lower relative value on cultural services as a whole than the groups of provisioning services and regulating services. This was unexpected because tourism, recreation, aesthetics, and intrinsic values all fall under the umbrella of cultural services. In contrast to the other stakeholder groups that placed a lower relative value on the cultural services as a whole, the conservation employees ranked all four of the ecosystem categories similarly. The low relative ranking of cultural services may not be synonymous with a perception of cultural services as having little value to stakeholders now or in the future because many cultural services are particularly difficult to assess (Chan et al. 2012, Daniel et al. 2012).

The more uniform distribution of the marbles (counters) among a suite of different ecosystem services by conservation practitioners is similar to the findings of Hicks et al. (2013). Their study, which asked fishermen, scientists, and managers living and working in Tanzania, Kenya, and Madagascar, to distribute counters between eight types of services, i.e., fishery, habitat, coastal protection, sanitation, tourism, education, cultural, and bequest, also found that managers were more inclined to assign similar levels of priority among an array of different types of services than local users and scientists because managers are often required to consider and balance multiple perspectives.
The high priority placed on domestic water, flood recession agriculture, and subsistence and commercial fisheries by the residents underscores the vital role of these specific provisioning services to the subsistence and economic well-being of the residents living in close proximity to the Wami River and Estuary, and parallels the recognition, rating, and/or ranking assigned by local communities in comparable empirical studies (Rönnbäck et al. 2007, Brown et al. 2008, Hussain and Badola 2010, Sodhi et al. 2010, Adekola et al. 2012, Kari and Korhonen-Kurki 2013). The high priority placed on habitat for riverine and estuarine flora and fauna versus the low priority assigned to the conservation of riverine and estuarine fauna further suggests that the residents are very reliant upon the natural capital. This follows the pattern noted by Roe and Walpole (2010) in which poorer individuals tend to focus on the direct use values of biodiversity versus the sustained presence of threatened species. Interestingly, however, the residents placed significantly higher values on aesthetics than the tourism officials and conservation employees. The appreciation of the beauty of mangrove ecosystems by local residents and fishermen has been noted in other studies (e.g., Rönnbäck et al. 2007, Iftekhar and Takama 2008, LópezMedellín et al. 2011), but comparisons between urban and rural respondents have found that the former place greater value on aesthetics and the existence value of biodiversity (Martín-López et al. 2012).

In this study we highlight the grave concerns of village residents for their sustenance and health. McNally et al. (2011) found that the mangrove forests in and around the Saadani River estuary had been subjected to intense harvesting for charcoal sale, threatening not only biodiversity but also the long-term viability of local fisheries. Efforts to protect the resources of Saadani National Park and raise the standard of living for local residents require the provision of ample, clean water and livelihood diversification. Planned expansion of ecotourism centered on the biodiversity of the Wami River has the potential to improve the livelihoods of local residents, which might translate into closer agreement of the village stakeholders with the high values placed on riverine and estuarine conservation by tourism and 
conservation stakeholders. The high priority given to the delivery of water and sediment to maintain nursery habitats is similar to the findings by Vilardy et al. (2011) and Warren-Rhodes et al. (2011), and highlights the residents understanding of the nexus with the abiotic factors influencing the composition and abundance of the fish and crustacean species they rely upon for their subsistence and livelihoods. An interesting disconnect, however, was the identification of increasing salinity levels as a main concern regarding the future conditions of the Wami River and its estuary by the residents and conservation employees juxtaposed against the very low levels of importance placed on the river's role in preventing the intrusion of saltwater upstream by all of the stakeholder groups. This, along with the low values assigned to the provision and maintenance of nursery habitats by tourism officials, clearly indicates a need for outreach activities.

\footnotetext{
${ }^{[1]}$ Exceptional resource values are defined as the "biophysical features of a national park that are assessed as being especially important to maintaining the unique ecological character and functions of the park and that provide outstanding social, economic and aesthetic benefits to local, national, and international stakeholders" (SANAPA 2009:8).

${ }^{[2]}$ Given that statistically significant differences between upstream and downstream residents were observed only for some of the specific provisioning services, the upstream and downstream residents were collapsed into one resident category for all of the other individual ecosystem services.
}

Responses to this article can be read online at: http://www.ecologyandsociety.org/issues/responses. $\mathrm{php} / 8611$

\section{Acknowledgments:}

We greatly appreciate the assistance of Jeremiah Daffa, Baraka Kalangahe, Appa Mandari, Gratian Luhikula, Esther Kapinga, Andrew Macha, Salim Ngomuo, Wilbard Mkama, Gerald Jacob, Winnie Kikoka, Bahati Joshua, Daniel Kisaka, Alberto Benedicto in coordinating and conducting the fieldwork. We are also grateful to Brian Crawford, Jim Tobey, and Elizabeth Anderson for their helpful comments on the survey instrument as well as Gerald Jacob for his assistance in entering data. Special thanks to the survey respondents and focus group participants who were so generous with their time and knowledge as well as the Village Chairmen, Village Executive Officers, and Saadani National Park personnel who were very helpful in the field. We thank the editor and peer reviewers of Ecology and Society for their helpful comments. This work was partially funded through the Coastal Institute of the University of Rhode Island.

\section{LITERATURE CITED}

Adams, W. M., D. Brockington, J. Dyson, and B. Vira. 2003. Managing tragedies: understanding conflict over common pool resources. Science 302:1915-1916. http://dx.doi.org/10.1126/ science. 1087771
Adekola, O., S. Morardet, R. de Groot, and F. Grelot. 2012. Contribution of provisioning services of the Ga-Mampa wetland, South Africa, to local livelihoods. International Journal of Biodiversity Science, Ecosystem Services \& Management 8 (3):248-264. http://dx.doi.org/10.1080/21513732.2012.671191

Agbenyega, O., P. J. Burgess, M. Cook, and J. Morris. 2009. Application of an ecosystem function framework to perceptions of community woodlands. Land Use Policy 26(3):551-557. http:// dx.doi.org/10.1016/j.landusepol.2008.08.011

Babbie, E. R., and L. Benaquisto. 2009. Fundamentals of social research. Second Canadian Edition. Nelson Education, Toronto, Canada.

Baldus, R. D., V. Beddoe, and J. Jafferji. 2007. Saadani National Park. Gallery Publications, Zanzibar.

Barbier, E. B., S. D. Hacker, C. Kennedy, E. W. Koch, A. C. Stier, and B. R. Silliman. 2011. The value of estuarine and coastal ecosystem services. Ecological Monographs 81(2):169-193. http:// dx.doi.org/10.1890/10-1510.1

Boyatzis, R. E. 1998. Transforming qualitative information: thematic analysis and code development. SAGE, Thousand Oaks, California, USA.

Braat, L. C., and R. de Groot. 2012. The ecosystem services agenda: bridging the worlds of natural science and economics, conservation and development, and public and private policy. Ecosystem Services 1(1):4-15. http://dx.doi.org/10.1016/j. ecoser.2012.07.011

Brown, K., T. Daw, S. Rosendo, M. Bunce, and N. Cherrett. 2008. Ecosystem services for poverty alleviation: marine \& coastal situational analysis. University of East Anglia, Norwich, England.

Carpenter, S. R., H. A. Mooney, J. Agard, D. Capistrano, R. S. DeFries, S. Diaz, T. Dietz, A. K. Duraiappah, A. Oteng-Yeboah, and H. M. Pereira. 2009. Science for managing ecosystem services: beyond the Millennium Ecosystem Assessment. Proceedings of the National Academy of Sciences 106(5):1305-1312. http://dx. doi.org/10.1073/pnas.0808772106

Chan, K. M. A., T. Satterfield, and J. Goldstein. 2012. Rethinking ecosystem services to better address and navigate cultural values. Ecological Economics 74(2012):8-18. http://dx.doi.org/10.1016/j. ecolecon.2011.11.011

Cohen, J. W. 1988. Statistical power analysis for the behavioral sciences. Second edition. Lawrence Erlbaum Associates, Hillsdale, New Jersey, USA.

Daily, G. C., S. Alexander, P. R. Ehrlich, L. Goulder, J. Lubchenco, P. A. Matson, H. A. Mooney, S. Postel, S. H. Schneider, D. Tilman, and G. M. Woodwell. 1997. Ecosystem services: benefits supplied to human societies by natural ecosystems. Issues in Ecology 2:1-16.

Daniel, T. C., A. Muhar, A. Arnberger, O. Aznar, J. W. Boyd, K. M. A. Chan, R. Costanza, T. Elmqvist, C. G. Flint, P. H. Gobster, A. Grêt-Regamey, R. Lavek, S. Muhar, M. Penkerm, R. G. Riben, T. Schauppenlehnerb, T. Sikoro, I. Soloviyp, M. Spierenburgq, K. Taczanowskab, J. Tame, and A. von der Dunk. 2012. 
Contributions of cultural services to the ecosystem services agenda. Proceedings of the National Academy of Sciences 109 (23):8812-8819. http://dx.doi.org/10.1073/pnas.1114773109

De Groot, R. S., M. A. Wilson, and R. M. J. Boumans. 2002. A typology for the classification, description and valuation of ecosystem functions, goods and services. Ecological Economics 41(3):393-408. http://dx.doi.org/10.1016/s0921-8009(02)00089-7

Granek, E. F., S. Polasky, C. V. Kappel, D. J. Reed, D. M. Stoms, E. W. Koch, C. J. Kennedy, L. A. Cramer, S. D. Hacker, E. B. Barbier, S. Aswani, M. Ruckelshaus, G. M. E. Perillo, B. R. Silliman, N. Muthiga, D. Bael, and E. Wolanski. 2010. Ecosystem services as a common language for coastal ecosystem-based management. Conservation Biology 24(1):207-216. http://dx.doi. org/10.1111/j.1523-1739.2009.01355.X

Gravetter, F. J., and L. B. Wallnau. 2004. Statistics for the behavioral sciences. Sixth edition. Wadsworth, Belmont, California, USA.

Hicks, C. C., N. A. J. Graham, and J. E. Cinner. 2013. Synergies and tradeoffs in how managers, scientists, and fishers value coral reef ecosystem services. Global Environmental Change 23 (6):1444-1453. http://dx.doi.org/10.1016/j.gloenvcha.2013.07.028

Hussain, S. A., and R. Badola. 2010. Valuing mangrove benefits: contribution of mangrove forests to local livelihoods in Bhitarkanika Conservation Area, east coast of India. Wetlands Ecology and Management 18(3):321-331. http://dx.doi.org/10.1007/ $\underline{\text { s11273-009-9173-3 }}$

Iftekhar, M. S., and T. Takama. 2008. Perceptions of biodiversity, environmental services, and conservation of planted mangroves: a case study on Nijhum Dwip Island, Bangladesh. Wetlands Ecology and Management 16(2):119-137. http://dx.doi.org/10.1007/ s11273-007-9060-8

Kari, S., and K. Korhonen-Kurki. 2013. Framing local outcomes of biodiversity conservation through ecosystem services: a case study from Ranomafana, Madagascar. Ecosystem Services 3:e32e39. http://dx.doi.org/10.1016/j.ecoser.2012.12.003

Korsgaard, L. 2006. Environmental flows in integrated water resources management: linking flows, services and values. Institute of Environment and Resources, Technical University of Denmark, Lyngby, Denmark.

Liquete, C., C. Piroddi, E. G. Drakou, L. Gurney, S. Katsanevakis, A. Charef, and B. Egoh. 2013. Current status and future prospects for the assessment of marine and coastal ecosystem services: a systematic review. PLoS ONE 8(7):e67737. http://dx.doi. org/10.1371/journal.pone.0067737

López-Medellín, X., A. Castillo, and E. Ezcurra. 2011. Contrasting perspectives on mangroves in arid northwestern Mexico: implications for integrated coastal management. Ocean \& Coastal Management 54(4):318-329. http://dx.doi.org/10.1016/ j.ocecoaman.2010.12.012

Mangora, M. M. 2011. Poverty and institutional management stand-off: a restoration and conservation dilemma for mangrove forests of Tanzania. Wetlands Ecology and Management 19 (6):533-543. http://dx.doi.org/10.1007/s11273-011-9234-2
Martín-López, B., I. Iniesta-Arandia, M. García-Llorente, I. Palomo, I. Casado-Arzuaga, D. G. D. Amo, E. GómezBaggethun, E. Oteros-Rozas, I. Palacios-Agundez, B. Willaarts, J. A. González, F. Santos-Martín, M. Onaindia, C. LópezSantiago, and C. Montes. 2012. Uncovering ecosystem service bundles through social preferences. PLOS ONE 7(6):e38970. http://dx.doi.org/10.1371/journal.pone.0038970

McNally, C. 2007. A follow-up dry season rapid ecological assessment of the Wami River Estuary, Tanzania. Coastal Resources Center, University of Rhode Island, Narragansett, Rhode Island, USA. [online] URL: http://www.crc.uri.edu/ download/Final August Estuary Report.pdf

McNally, C. G., E. Uchida, and A. J. Gold. 2011. The effect of a protected area on the tradeoffs between short-run and long-run benefits from mangrove ecosystems. Proceedings of the National Academy of Sciences 108(34):13945-13950. http://dx.doi. org/10.1073/pnas.1101825108

McShane, T. O., P. D. Hirsch, T. C. Trung, A. N. Songorwa, A. Kinzig, B. Monteferri, D. Mutekanga, H. V. Thang, J. L. Dammert, M. Pulgar-Vidal, M. Welch-Devine, J. P. Brosius, P. Coppolillo, and S. O'Connor. 2011. Hard choices: making tradeoffs between biodiversity conservation and human well-being. Biological Conservation 144(3):966-972. http://dx.doi.org/10.1016/ j.biocon.2010.04.038

Menzel, S., and J. Teng. 2010. Ecosystem services as a stakeholderdriven concept for conservation science. Conservation Biology 24 (3):907-909. http://dx.doi.org/10.1111/j.1523-1739.2009.01347.x

Millenium Ecosystem Assessment. 2005. Ecosystems and human well-being: wetlands and water synthesis. World Resources Institute, Washington, D.C., USA.

Myers, N., R. A. Mittermeier, C. G. Mittermeier, G. A. B. da Fonseca, and J. Kent. 2000. Biodiversity hotspots for conservation priorities. Nature 403(6772):853-858. http://dx.doi.org/10.1038/35002501

Nakagawa, S., and I. C. Cuthill. 2007. Effect size, confidence interval and statistical significance: a practical guide for biologists. Biological Reviews 82(4):591-605. http://dx.doi. org/10.1111/j.1469-185x.2007.00027.x

Needles, L. A., S. E. Lester, R. Ambrose, A. Andren, M. Beyeler, M. S. Connor, J. E. Eckman, B. A. Costa-Pierce, S. D. Gaines, K. D. Lafferty, H. S. Lenihan, J. Parrish, M. S. Peterson, A. E. Scaroni, J. S. Weis, and D. E. Wendt. 2015. Managing bay and estuarine ecosystems for multiple services. Estuaries and Coasts 38 (Supplemental 1):35-48. http://dx.doi.org/10.1007/s12237-013-9602-7

Pereira, E., C. Queiroz, H. M. Pereira, and L. Vicente. 2005. Ecosystem services and human well-being: a participatory study in a mountain community in Portugal. Ecology and Society 10 (2): 14 .

Pollnac, R. B., and B. R. Crawford. 2000. Assessing behavioral aspects of coastal resource use. Coastal Resources Center, University of Rhode Island, Narragansett, Rhode Island, USA.

Republic of Tanzania, United Nations Development Programme, and Global Environment Facility. [date unknown]. Extending the Coastal Forest Protected Area Subsystem in Tanzania. Tanzania Forest Services Agency, Dar es Salaam, Tanzania. 
Research and Analysis Working Group. 2005. Poverty and human development report. Mkuki na Nyota Publishers, Dar es Salaam, Tanzania.

Roe, D., and M. J. Walpole. 2010. Whose value counts? Tradeoffs between biodiversity conservation and poverty reduction Pages 157-174 in N. Leader-Williams, W. M. Adams, and R. J. Smith, editors. Trade-offs in conservation: deciding what to save. Conservation Science and Practice Series, No. 8. Wiley-Blackwell, Oxford, UK.

Rönnbäck, P., B. Crona, and L. Ingwall. 2007. The return of ecosystem goods and services in replanted mangrove forests: perspectives from local communities in Kenya. Environmental Conservation 34(4):313-324. http://dx.doi.org/10.1017/s0376892907004225

Saadani National Park (SANAPA). 2005. Saadani National Park management zone plan. SANAPA, Arusha, Tanzania.

Saadani National Park (SANAPA). 2009. Saadani National Park general management plan. SANAPA, Arusha, Tanzania.

Sarmett, J., and E. P. Anderson. 2008. Wami River initial environmental flow assessment synthesis report. Coastal Resources Center, University of Rhode Island, Narragansett, Rhode Island, USA, Wami Ruvu Water Basin Office, Morogoro, Tanzania, and Florida International University, Miami, Florida, USA.

Saunders, J., N. Beaumont, J. P. Atkins, A. Lannin, D. Lear, E. Ozdemiroglu, and T. Potts. 2015. A review of marine and coastal ecosystem services data and tools to incorporate this into decision-making. Pages 145-164 in R. K. Turner, M. Schaafsma, editors. Coastal zones ecosystem services: from science to values and decision making. Springer International, Dordrecht, The Netherlands. http://dx.doi.org/10.1007/978-3-319-17214-9 8

Sigalla, H. L. 2013. Trade-offs between wildlife conservation and local livelihood: evidence from Tanzania. African Review 40 (1):155-178.

Sodhi, N. S., T. M. Lee, C. H. Sekercioglu, E. L. Webb, D. M. Prawiradilaga, D. J. Lohman, N. E. Pierce, A. C. Diesmos, M. Rao, and P. R. Ehrlich. 2010. Local people value environmental services provided by forested parks. Biodiversity and Conservation 19(4):1175-1188. http://dx.doi.org/10.1007/s10531-009-9745-9

Tobey, J. 2008. A profile of the Wami River Sub-Basin. Coastal Resources Center, University of Rhode Island, Narragansett, Rhode Island, USA.

Torell, E., C. A. Redding, C. L. Blaney, E. Hernandez, O. Sison, J. Dyegula and D. D. Robadue Jr. 2012. Population, health, and environment situation analysis for the Saadani National Park Area, Tanzania. Ocean \& Coastal Management 66:1-11. http://dx. doi.org/10.1016/j.ocecoaman.2012.05.005

Twilley, R. R., and V. H. Rivera-Monroy. 2009. Ecogeomorphic models of nutrient biogeochemistry for mangrove wetlands in coastal wetlands: an integrated ecosystem approach. Pages 641-683 in G. M. E. Perillo, E. Wolanski, D. R. Cahoon, M. M. Brinson, editors. Coastal wetlands: an integrated ecosystem approach. Elsevier, Amsterdam, The Netherlands.

Vilardy, S. P., J. A. González, B. Martín-López, and C. Montes. 2011. Relationships between hydrological regime and ecosystem services supply in a Caribbean coastal wetland: a social-ecological approach. Hydrological Sciences Journal 56(8):1423-1435. http:// dx.doi.org/10.1080/02626667.2011.631497

Vira, B., B. Adams, C. Agarwal, S. Badiger, R. A. Hope, J. Krishnaswamy, and C. Kumar. 2012. Negotiating trade-offs: choices about ecosystem services for poverty alleviation. Economic and Political Weekly 47(9):67-75.

Warren-Rhodes, K., A.-M. Schwarz, L. N. Boyle, J. Albert, S. S. Agalo, R. Warren, A. Bana, C. Paul, R. Kodosiku, W. Bosma, D. Yee, P. Rönnbäck, B. Crona, and N. Duke. 2011. Mangrove ecosystem services and the potential for carbon revenue programmes in Solomon Islands. Environmental Conservation 38 (4):485-496. http://dx.doi.org/10.1017/s0376892911000373 